\title{
Efeito do Gene do Estresse Suíno sobre Características de Quantidade e Qualidade de Carcaça ${ }^{1}$
}

\author{
Reginaldo Gaspar Bastos ${ }^{2}$, Joreci Federizzi ${ }^{3}$, João Carlos Deschamps ${ }^{4}$, \\ Ricardo Alberto Cardellino5, Odir Antonio Dellagostin 6
}

\begin{abstract}
RESUMO - O gene do estresse suíno (gene hal), em homozigose recessiva ( $n n$ ), está associado com a ocorrência da Síndrome do Estresse Porcino (PSS) e com a ocorrência da carne pálida, mole e exudativa (PSE). Em heterozigose (Nn), está relacionado com diminuição na qualidade da carne porém, com maior peso de carcaça. Neste estudo, foi caracterizado o genótipo do gene hal de 160 suínos por meio de análise do DNA extraído de um único folículo piloso. Estes animais foram abatidos e, após, mensuradas características de carcaça de cada um. Entre os 160 animais analisados, $82(52,58 \%)$ foram caracterizados como $N N, 67(41,80 \%)$ como $N n$ e nove $(5,62 \%)$ como $n n$. A variação das características de carcaça entre os genótipos foi avaliada por análise de variância, usando o SAS. Os animais dos três genótipos não diferiram quanto ao peso da carcaça quente, à espessura de toucinho, profundidade de músculo, porcentagem de carne magra e cor do músculo longissimus dorsi. Entretanto, a variação da cor ao longo da carcaça foi menor em animais $N N(40,82 \%)$ do que em $N n$ $(49,77 \%)$ e $n n(53,83 \%)$. Estes resultados indicam que a presença do gene hal tanto em heterozigose como em homozigose recessiva não está associada ao maior peso de carcaça e a utilização destes animais pode acarretar em perda na qualidade da carne. Devido a isto, o uso intencional de animais homozigotos recessivos ou heterozigotos em programas de cruzamento deve ser desestimulado.
\end{abstract}

Palavras-chave: carcaça suína, gene halotano, PCR, PSE, PSS

\section{Effect of Swine Stress Gene on Quality and Quantity of Carcass}

\begin{abstract}
The swine stress gene ( $h a l$ gene) in recessive homozygosis $(n n)$ is associated with the occurrence of the Porcine Stress Syndrome (PSS) and with the occurrence of pale, soft and exudative pork (PSE). In heterozygosis ( $\mathrm{Nn}$ ) it is related to low quality of carcass, but higher carcass weight. This study has characterized the genotype of hal gene by DNA-testing, obtained by alkaline extraction from a single hair root, in a sample of 160 swines. These animals were slaughtered and carcass traits for each animal were measured. Among the 160 animals, $82(52.58 \%)$ were identified as $N N, 67(41.80 \%)$ as $N n$, and $9(5.62 \%)$ as $n n$. Variation in carcass traits across genotypes was evaluated by analysis of variance, using SAS. The $N N, N n$ and $n n$ animals did not differ for: hot carcass weight, backfat thickness, muscle depth, lean meat percentage, and longissimus dorsi muscle color. However, variation in carcass color was lower for $N N(40.82 \%)$ than for $N n(49.77 \%)$ and $n n(53.83 \%)$ animals. These results indicate that the presence of hal gene in heterozygosis or recessive homozigosis was not associated with better carcass weight and the utilization of these animals may lead to lower carcass quality. Therefore, the intentional use of heterozygous and recessive homozygous animals should not be encouraged.
\end{abstract}

Key Words: swine carcass, halothane gene, PCR, PSE, PSS

\section{Introdução}

O gene do estresse suíno, também chamado de gene halotano (gene hal), codifica para canais liberadores de cálcio (CRC) do retículo sarcoplasmático do músculo esquelético (FUJII et al., 1991). O gene hal em homozigose recessiva (nn) está associado com o aparecimento da Síndrome do Estresse Porcino (PSS), que, por sua vez, está relacionada com a mortalidade durante o transporte $\mathrm{e}$ com o aparecimento das características de carne pálida, mole e exudativa (PSE) (SWATLAND, 1982; SATHER et al., 1991; GEERS et al., 1994). Quando em heterozigose $(\mathrm{N} n)$, o gene hal mantém relação com a diminuição da qualidade de carne (ZHANG et al., 1992; LEACH et al., 1996), mas estes mesmos autores e FÁVERO (1997) demonstraram que animais $N n$ ganham mais peso quando comparados aos homozigotos normais $(N N)$.

Foi possível, por meio do teste de exposição ao

\footnotetext{
1 Trabalho realizado com o apoio da Fundação de Amparo a Pesquisa do Estado do Rio Grande do Sul (FAPERGS) (proc. 98/02179).

2 Doutorando em Biotecnologia - Centro de Biotecnologia - UFPel. E-mail: rgbastos@ufpel.tche.br

3 Médico Veterinário. E-mail: tim@ufpel.tche.br

4 Prof. Adjunto - Faculdade de Veterinária - Centro de Biotecnologia - UFPel. E.mail: deschamp@ufpel.tche.br

5 Prof. Adjunto - Depto. de Zootecnia - FAEM - UFPel. E-mail: rcard@ufpel.tche.br

6 Prof. Adjunto - Instituto de Biologia - Centro de Biotecnologia - UFPel. E-mail: odir@ufpel.tche.br
} 
anestésico Halotano, caracterizar o gene hal e determinar que todas as raças suínas são suscetíveis a PSS e, portanto, predispostas ao desenvolvimento da carne PSE. Porém, a incidência de PSE é maior naquelas raças com alto índice de carne magra, mais musculosas e com crescimento rápido, como Pietrain, Landrace e Poland China (MCGLOUGHLIN, 1980). Recentemente, o gene hal vem sendo caracterizado por análise do DNA, por intermédio da Reação em Cadeia da Polimerase (PCR), seguido de digestão com endonuclease de restrição. Para esta caracterização molecular, sangue ou biopsia de músculo são comumente usados como fonte de DNA genômico (OTSU et al., 1991; CHEAK et al., 1994; BAUEROVA et al., 1995).

A partir do conhecimento da condição do gene hal em rebanhos suínos, estratégias de produção podem ser traçadas para atender com qualidade o mercado consumidor. Assim, objetivou-se no presente trabalho a caracterização rápida do genótipo do gene hal, utilizando como fonte de DNA o folículo piloso, e a determinação do efeito deste genótipo sobre as características de carcaça de suínos criados e abatidos em condições comerciais.

\section{Material e Métodos}

Para o estudo foram escolhidos aleatoriamente 160 animais híbridos das raças Large White, Landrace, Duroc e Pietrain do setor de terminação de uma unidade comercial localizada no Estado do Rio Grande do Sul. A população, com peso vivo entre 90 e $100 \mathrm{~kg}$, foi abatida em um frigorífico comercial localizado, igualmente no Rio Grande do Sul. A distância percorrida entre a unidade de produção e o abatedouro foi de $350 \mathrm{~km}$, e o abate ocorreu no mês de novembro. $\mathrm{O}$ embarque e transporte dos animais ocorreram segundo o manejo da unidade de produção.

O transporte foi realizado no período da noite, sendo utilizada uma lotação de $0,4 \mathrm{~m}^{2} /$ animal. Por ocasião da chegada dos animais ao abatedouro, verificou-se que quatro animais haviam morrido durante o transporte. O manejo de abate obedeceu as normas do frigorífico, sendo que, após o atordoamento, os animais foram sangrados, e o intervalo do atordoamento à sangria não ultrapassou 5 segundos. Após o sangramento, foram coletadas cerdas de todos os animais, e estes sofreram escalda a $60^{\circ} \mathrm{C}$ e demais práticas de manejo de abate.

Medidas de peso da carcaça quente em kg (PCQ), espessura de toucinho em mm (ET), profundidade de músculo em mm (PM), percentual de carne magra (CM), cor do músculo longissumus dorsi em absorbância (COR) e percentual de variação de cor ao longo da carcaça (VCOR) foram obtidos de cada animal com o uso de pistola eletrônica (Hennessy Grading System Probe GP4). A cor do músculo foi obtida com um comprimento de onda de $590 \mathrm{~nm}$ e a variação de cor ao longo da carcaça foi medida pelo Hennessy Grading System Probe GP4.

DNA genômico foi extraído de um único folículo piloso, segundo o protocolo descrito por BASTOS et al. (2000). A técnica de PCR foi utilizada para amplificação de um fragmento de DNA de 81 pares de bases (pb) específico do gene hal (FUJII et al., 1991) e o produto do PCR foi digerido com a enzima de restrição $C f o$ I (GIBCO-BRL). A digestão com $C f o$ I produz dois fragmentos de DNA em animais $N N$, um de $49 \mathrm{pb}$ e outro de $32 \mathrm{pb}$; três fragmentos em animais $N n, 81,49$ e 32 pb; e um único fragmento não digerido de $81 \mathrm{pb}$ em animais $n n$. O produto da digestão foi analisado por eletroforese em gel de agarose (SAMBROOK et al., 1989).

As variáveis PCQ, ET, PM, CM, VCOR e COR foram analisadas, em relação aos diferentes genótipos do gene $h a l$, usando o procedimento GLM do SAS, de acordo com o modelo: $Y_{i j}=m+G_{i}+e_{i j}$, em que $Y_{i j}$ corresponde à variável analisada; $m$, a média geral; $G_{i}$, ao genótipo ( $N N, N n$ e $\left.n n\right)$ e $e_{i j}$, ao erro experimental. A diferença mínima significativa entre as médias foi obtida utilizando o teste " $t$ " de Student do procedimento GLM do SAS.

\section{Resultados e Discussão}

A caracterização do gene hal por meio de análise do DNA por endonuclease de restrição permitiu detectar, na população estudada, os três padrões genotípicos deste gene ou seja, animais $N N, N n$ e $n n$. Ao contrário da caracterização pela exposição ao anestésico Halotano, a técnica molecular permite a clara identificação dos animais heterozigotos (HOUDE et al., 1993; REMPEL et al., 1993; WEBB, 1996). A extração de DNA genômico de folículo piloso mostrou-se um método rápido, eficiente e simples, que torna a caracterização molecular do gene hal aplicável a qualquer animal dentro do sistema de produção (BAUEROVA et al., 1995; BASTOS et al., 2000).

A freqüência genotípica do gene hal na população estudada foi de $84(52,58 \%)$ animais $N N, 67$ $(41,80 \%) \mathrm{Nn}$ e nove $(5,62 \%) n n$. De acordo com 
MURRAY et al. (1989), em uma população de suínos escolhida aleatoriamente, a freqüência esperada do gene hal seria de $23 \%$ para $\mathrm{Nn}$ e $1,8 \%$ para animais $n n$. Esta discordância entre freqüência esperada e encontrada, provavelmente, pode ser atribuída à prática de manejo da unidade de produção suinícola analisada, a qual seleciona animais de reposição com base somente no ganho de peso e na espessura de toucinho. Segundo JONES et al. (1994), esta prática de manejo acarreta aumento na freqüência do alelo recessivo do gene hal.

Entre os quatro animais que morreram no transporte da granja para o abatedouro, três foram caracterizados como $n n$ e um como $N n$. Não foi feita a tipificação de carcaça destes animais, porém este dado isolado indica possível relação entre a presença do alelo recessivo do gene hal e a mortalidade ao transporte, o que está de acordo com MURRAY et al. (1989) e GEERS et al. (1994).

Os resultados médios e erros-padrão dos parâmetros de carcaça, assim como o número de animais analisados dentro de cada genótipo do gene hal, são apresentados na Tabela 1 .

Os resultados médios de PCQ, ET, PM, CM e COR não diferiram $(\mathrm{P}<0,05)$ entre os três genótipos

Tabela 1 - Médias e erros-padrão das características de carcaça dos animais nos genótipos do gene hal

Table 1 - Means and standard errors of carcass traits of animals of hal gene genotypes

\begin{tabular}{|c|c|c|c|}
\hline \multirow{2}{*}{$\begin{array}{l}\text { Característica } \\
\text { da carcaça } \\
\text { Carcass trait }\end{array}$} & \multicolumn{3}{|c|}{$\begin{array}{l}\text { Genótipo }\left(\mathrm{n}^{\mathrm{o}}\right) \\
\text { Genotype }(n .)\end{array}$} \\
\hline & $N N^{1}(82)^{2}$ & $N n(67)$ & $n n(06)$ \\
\hline $\mathrm{PCQ}^{3}(\mathrm{~kg})$ & $73,80(7,862)^{4}$ & $74,41(7,904)$ & $69,13(8,462)$ \\
\hline $\mathrm{ET}(\mathrm{mm})$ & $21,32(4,650)$ & $20,07(4,290)$ & $21,26(4,895)$ \\
\hline $\mathrm{PM}(\mathrm{mm})$ & $48,58(6,317)$ & $49,30(8,567)$ & $46,20(8,514)$ \\
\hline $\mathrm{CM}(\%)$ & $52,51(2,879)$ & $53,28(2,773)$ & $52,26(3,605)$ \\
\hline COR(absorb) & $51,34(6,033)$ & $50,83(6,981)$ & $55,33(7,916)$ \\
\hline $\operatorname{VCOR}(\%)$ & $40,82^{a}(12,96)$ & $49,77^{\mathrm{b}}(23,19)$ & $53,83^{\mathrm{c}}(41,619)$ \\
\hline \multicolumn{4}{|c|}{$\begin{array}{l}1 N N \text { - homozigoto dominante; } N n \text { - heterozigoto; } n n \text { - homozigoto } \\
\text { recessivo. }\end{array}$} \\
\hline \multicolumn{4}{|c|}{$\begin{array}{l}3 \text { PCQ - peso da carcaça quente; ET - espessura de toucinho } \\
\text { PM - profundidade de músculo; CM - carne magra da carcaça } \\
\text { COR - cor do músculo longissimus; VCOR - variação de cor ao } \\
\text { longo da carcaça. } \\
\text { Os valores seguidos de letras diferentes, na mesma linha, são }\end{array}$} \\
\hline \multicolumn{4}{|c|}{4 Erros-padrão. } \\
\hline \multirow{2}{*}{\multicolumn{4}{|c|}{$\begin{array}{l}1 \text { NN- normal homozygote; Nn - heterozygote; } n n \text { - recessive homozygote. } \\
2 \text { Number of analyzed animals. }\end{array}$}} \\
\hline & & & \\
\hline \multicolumn{4}{|c|}{$\begin{array}{l}3 \text { PCQ - hot carcass weight; ET - backfat tickness; PM - muscle deepth; } \\
C M \text { - percentage lean meat; COR-longissimus muscle color; VCOR-color } \\
\text { variation in carcass. }\end{array}$} \\
\hline \multicolumn{4}{|c|}{4 Standard errors. } \\
\hline
\end{tabular}

do gene hal. Por outro lado, os valores médios de VCOR diferiram $(\mathrm{P}<0,05)$ entre os diferentes genótipos, sendo que menor VCOR foi encontrada em animais $N N$ do que em $N n$ e $n n$ (Tabela 1).

Segundo GEERS et al. (1994), os animais $N n$, quando criados e abatidos em condições experimentais, podem apresentar melhor desempenho quanto à quantidade de carne magra na carcaça e espessura de toucinho, entretanto sofrem mais os efeitos do manejo e abate. Nas condições em que este estudo foi realizado, os animais $N n$ não apresentaram melhor desempenho quanto à quantidade de carne na carcaça e espessura de toucinho, quando comparados com os $N N$. Assim, pode ser sugerido que as práticas de criação, as quais envolvem o manejo da granja, o transporte dos animais para o frigorífico e as condições de abate podem afetar negativamente mais os animais $N n$ do que os $N N$.

Neste estudo foi possível avaliar o efeito do genótipo do gene hal sobre parâmetros de qualidade e quantidade da carne suína. Esta avaliação foi facilitada pela utilização de técnicas moleculares de caracterização gênica. Além disso, a utilização do folículo piloso como fonte de DNA genômico otimizou a execução da técnica. A população de suínos analisada foi completamente heterogênia, representando uma amostragem aleatória de um rebanho comercial.

\section{Conclusões}

Os resultados deste estudo indicam que o gene hal tanto em heterozigose como em homozigose recessiva provoca efeito negativo na variação de cor da carcaça suína. Concomitantemente, não houve melhora nos parâmetros de quantidade de carne em animais heterozigotos ou em homozigotos recessivos. Assim, a utilizacão destes animais em programas de cruzamento não deve ser estimulada.

\section{Referências Bibliográficas}

BASTOS, R.G., FEDERIZZI, J., DESCHAMPS, J.C. et al. 2000. Characterization of swine stress gene by DNA-testing using plucked hair as a source of genomic DNA. Genetics and Molecular Biology,v.23, n.4 (aceito para publicação).

BAUEROVA, M., VASICEK, D., UHRIN, P. et al. 1995. Detection of malignant hyperthermia in pigs by DNA-test using plucked hair as a source of DNA. Pig News Inf., 16:109N-111N.

CHEAK, K.S., CHEAK, A.M., KRAUSGRILL, D.I. 1994. Identification of variations in meat quality in live pigs free of the halothane gene using biopsy samples of muscle longissimus dorsi. Pigs News Inf., 15:55-57. 
FÁVERO, J.A. Influência do gene halotano sobre o desempenho produtivo de suínos. In: CONGRESSO NACIONAL DA ASSOCIAÇÃO BRASILEIRA DE VETERINÁRIOS ESPECIALISTAS EM SUÍNOS, 8, 1997, Foz do Iguaçu. Anais...Foz do Iguaçu: ABRAVES, 1997, p.395-396.

FUJII, J., OTSU, K., ZORZATO, F. et al. 1991. Identification of a mutation in porcine ryanodine receptor associated with malignant hyperthermia. Science, 253:448-451.

GEERS, R., BLEUS, E., Van SCHIE, T. et al. 1994. Transport of pig different with respect to the Halothane Gene: stress assessment. J. Anim. Sci., 72:2552-2558.

HOUDE, A., PROMMIER, S.A., ROY, R. 1993. Detection of the ryanodine receptor mutation associated with malignant hyperthermia in purebred swine populations. J. Anim. Sci., 77:1414-1418.

JONES, S.D.M., CLIPLEF, R.L., FORTIN, A.F. et al. 1994. Production and ante-morten factors influencing pork quality. Pig News Inf., 15:15N-18N.

LEACH, L.M., ELLIS, M., SUTTON, D.S. et al. 1996. The growth performance, carcass characteristics, and meat quality of halothane carrier and negative pigs. J. Anim. Sci., 74:934-943.

MCGLOUGHLIN, P. Genetics aspects of pig meat quality. 1980. Pig News Inf., 1:1p.

MURRAY, A.C., JONES, S.D.M., SATHER, A.P. 1989. The effect of preslaughter feed restriction and genotype for stress suscetibility on pork quality and composition. Can. J. Anim. Sci., 69:83-91.
OTSU, K., KHANNA, V.K., ARCHIBALD, A.L. 1991. Cosegregation of porcine malignant hyperthermia and a probable causal mutation in the skeletal muscle ryanodine receptor gene in backcross families. Genomics, 11:744.

REMPEL, W.E., LU, M., KANDELGY, S. et al. 1993. Relative accuracy of the halothane challenge test and molecular genetic test in detecting the gene for porcine stress syndrome. J. Anim. Sci., 71:1395-1399.

SAMBROOK, J., FRITSCH, E.F., MANIATIS, T. 1989. Molecular Cloning: A Laboratory Manual. 2.ed. New York: Cold Spring Harbor Laboratory. 18. 88p.

SATHER, A.P., JONES, S.D.M., TONG, A.K.W. et al. 1991. Halothane genotype by interactions on pig meat quality. Can. J. Anim. Sci., 71:645-658

SWATLAND, H.J. 1982. The challenge of improving meat quality. Can. J. Anim. Sci., 62:15-24.

ZHANG, W., KUHLERS, D. L., REMPEL, W.E. 1992. Halothane gene and swine performance. J. Anim. Sci., 70:1307-1313.

WEBB, A.J. 1996. Future challenges in pig genetics. Pig News Inf., $17: 11 \mathrm{~N}-16 \mathrm{~N}$.

Recebido em: 18/12/98

Aceito em: 27/09/00 